\title{
$\mathrm{CRLH}$ 전송 선로 구조를 이용한 이중 대역 전력 분배기
}

\section{Dual-Band Power Divider Using CRLH-TL}

\author{
김승환 · 손강호 · 김일규 · 김 영 · 이영순 · 윤영철* \\ Seung-Hwan Kim · Kang-Ho Sohn - Ell-Kou Kim - Young Kim • \\ Young-Soon Lee Young-Chul Yoon*
}

요 약

본 논문에서는 메타 재질을 이용하여 이중 대역에서 동작하는 전력 분배기를 제안하였다. 여기에서 사용된 메타 재질은 left-hand 특성을 인위적으로 캐패시터와 인덕터로 구현하고, 이것의 파라스틱 성분에 의한 Righthand 성분이 추가된 CRLH 전송 선로로 구현하였다. 이러한 CRLH 전송 선로 특성을 이용하여 기존 Gysel이 고안한 전력 분배기와 결합하여 고 전력에서 사용이 가능하고 이중 대역에서 동작하는 전력 분배기를 제작하였 다. 본 논문에서 제작한 전력 분배기는 $0.88 \mathrm{GHz}$ 와 $1.67 \mathrm{GHz}$ 이중 대역에서 동작하고, 각 주파수에서 $21.0 \mathrm{~dB}$, $15.8 \mathrm{~dB}$ 의 반사 계수와 $3.83 \mathrm{~dB}, 3.64 \mathrm{~dB}$ 의 삽입 손실을 확인하였다. 또한, 각 출력 포트 간의 위상차는 $3 \sim 6^{\circ}$ 됨을 확인하였다.

\section{Abstract}

This paper proposes a power divider based on meta-material structure with dual-band operation. The meta-material structures of left-hand characteristic are constituted of series capacitors and shunt inductors, but they have parasitic series inductance and shunt capacitance effects. There is represented the composite right/left-handed transmission line (CRLH-TL) model. When the power divider is implemented by using the CRLH-TL, the power divider can operate dual band. To verify the power divider with dual band, we are implemented to operate dual-band that is $0.88 \mathrm{GHz}$ and $1.67 \mathrm{GHz}$. The characteristics of divider have the return loss less than each $21.0 \mathrm{~dB}$ and $15.8 \mathrm{~dB}$ and the insertion loss better than $3.83 \mathrm{~dB}$ and $3.64 \mathrm{~dB}$ at each frequency. Also, the output phase difference is $3 \sim 6^{\circ}$.

Key words : Power Divider, CRLH-TL, Dual-Band

\section{I. 서 론}

통신 분야의 발전으로 인해 높은 화질의 사진, 음 악 파일, DMB 서비스 등이 하나의 단말기로 이용이 가능해지게 되면서 대용량으로 데이터를 전송해야 하는 경우가 발생하게 되고, 이러한 서비스는 기존 에 사용하는 주파수의 대역 이외에 또 다른 대역의 주파수를 사용을 필요로 한다. 이 때문에 하나 이상 의 대역에서 사용이 가능한 여러 가지 장비를 개발
하는 것이 필요하게 된다.

이러한 필요에 의해 연구는 진행되었고, 사용자의 용도에 따라 많은 디바이스들이 개발되었다. 예를 들면 C. Caloz는 CRLH-TL을 도입하여 일반적인 월 킨슨 전력 분배기를 이중 대역으로 동작할 수 있도 록 설계하였담] 이 외에도 전송 선로를 다단으로 연결하여 광대역에서 동작하는 전력 분배기, T-접합 방식을 이용하여 고주파에서도 사용이 가능한 전력 분배기, Split-Tee 전력 분배기 등이 개발되었다 ${ }^{[2]-[4]}$.

\footnotetext{
「본 연구는 금오공과대학교 학술연구비에 의하여 연구된 논문입니다.J

금오공과대학교 마이크로회로설계 연구실(RF Circuit Design Lab, Kumoh National Institute of Technology)

*관동대학교 전자정보통신공학과(Electronics and Information Communication Engineering, Kwandong University)

·논 문 번 호 : 20080523-06S

- 수정완료일자 : 2008년 7월 8일
} 
여기서 메타 재질(Meta-Material: MTM)은 유전율 과 투자율이 음의 값을 가지게 되면 일반 물질과 다 른 전자파 전파 톡성을 갖게 된다는 것을 1968년 러 시아 과학자 Veselego가 발표한 논문을 기초한 이론 [5]으로, left-handed 톡성은 직렬 캐패시턴스 값과 병 렬 인덕턴스 값이 결합하여 음의 위상 속도를 나타 내는 특성을 갖고 있으며, 이것을 실제 구현시 기생 적으로 생기는 직렬 인덕턴스와 병렬 인덕턴스 값에 의해서 composite right/left-handed(CRLH) 전송 선로 특성을 갖는다는 것이다 ${ }^{[6]}$.

현재는 CRLH 전송 선로 특성을 이용하여 안테나, 수동 소자 등에 다양한 구조들이 제안되어 연구되고 있다. 이렇게 연구되어진 이론을 바탕으로 현재에는 이중 대역 동작 특성을 가지는 브랜치 라인, 링 하 이브리드 등 많은 수의 디바이스들이 연구되어져 있 다 [7],18].

본 논문은 기존의 방법 ${ }^{[2]-[4]}$ 즉, 선형적인 분산 특 성을 이용한 것과 다르게 CRLH 전송 선로의 비선형 적 분산 특성을 이용하여 마이크로웨이브 분야에서 이용되는 전력 분배기 ${ }^{[9]}$ 에 대한 해석 방법과 $\mathrm{CRLH}$ 전송 선로의 이중 대역 특성을 적용하여 이중 대역 에서 사용이 가능한 전력 분배기를 제안하였다.

\section{II. 이중 대역을 갖는 전력 분배기 설계}

\section{2-1 전력 분배기 해석}

그림 1에서 보는 바와 같이 Gysel은 저 전력 분배 기의 단점을 보완한 새로운 형태의 고 전력 분배기 를 제안하였다.

그림 1은 고 전력 분배기의 회로도이다.

이 회로의 전달 특성을 유도하기 위해서 우 모드 와 기 모드 분석을 하였다 ${ }^{[0],[11]}$. 입력이 포트 2 또는 포트 3로 입력될 경우, 그림 1을 우 또는 기 모드로 해석하기 위한 등가 회로를 그림 2와 같이 나타낼 수 있다.

그림 2의 우와 기 모드의 $\mathrm{ABCD}$ 파라미터를 구하 면 다음과 같다.

$$
\left[\begin{array}{ll}
A & B \\
C & D
\end{array}\right] \text { even }=\left[\begin{array}{cc}
0 & j \sqrt{2} Z_{0} \\
\frac{j}{\sqrt{2} Z_{0}} & 0
\end{array}\right]
$$

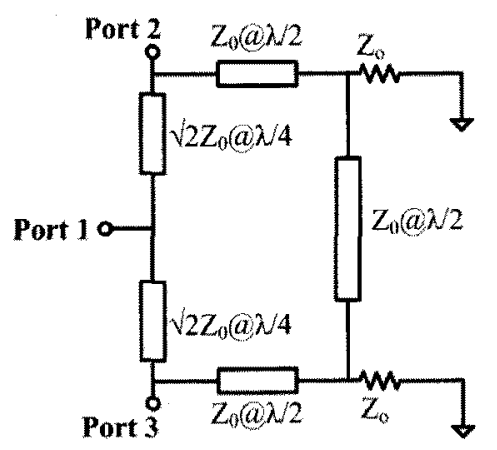

그림 1. 고 전력 분배기 회로도

Fig. 1. Schematic of high power divider.

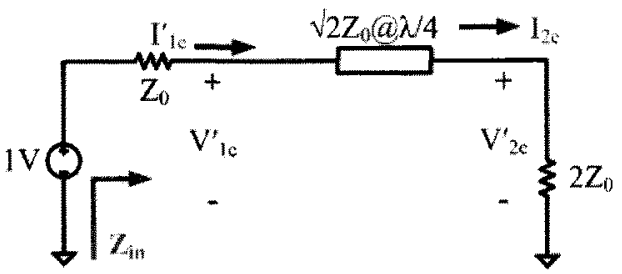

(a) 우 모드

(a) Even mode

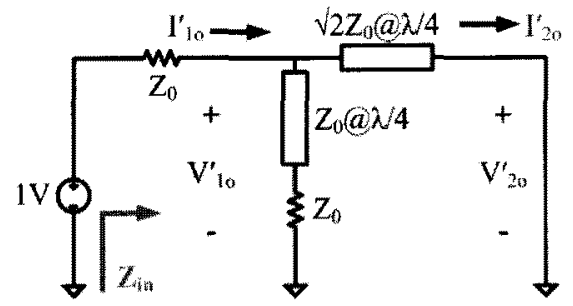

(b) 기 모드

(b) Odd mode

그림 2. 입력 포트 2 또는 3일 때 등가회로

Fig. 2. Equivalent circuit when port 2 or port 3 is excited.

$$
\begin{aligned}
{\left[\begin{array}{ll}
A & B \\
C & D
\end{array}\right] \text { odd } } & =\left[\begin{array}{cc}
1 & 0 \\
\frac{1}{Z_{0}} & 1
\end{array}\right]\left[\begin{array}{cc}
0 & j \sqrt{2} Z_{0} \\
\frac{j}{\sqrt{2} Z_{0}} & 0
\end{array}\right] \\
& =\left[\begin{array}{cc}
0 & j \sqrt{2} Z_{0} \\
\frac{j}{\sqrt{2} Z_{0}} & j \sqrt{2}
\end{array}\right]
\end{aligned}
$$

$V_{1 e}=\frac{1}{2}, I_{1 e}^{\prime}=\frac{1}{2 Z_{0}}, V_{2 e}^{\prime}=\frac{-j}{\sqrt{2}}, I_{2 e}^{\prime}=\frac{-i}{2 \sqrt{2 Z_{0}}}$ $V_{10}^{\prime}=\frac{1}{2}, I_{10}^{\prime}=\frac{1}{2 Z_{o}}, V_{2 o}^{\prime}=0, I_{2 o}^{\prime}=\frac{-i}{2 \sqrt{2 Z_{o}}}$

가 된다. 
이로부터 입력 포트가 2 또는 3일 때

$$
\begin{aligned}
& V_{1}=V_{2 e}^{\prime}+V_{20}^{\prime}=\frac{-j}{\sqrt{2}}, I_{1}=I_{2 e}^{\prime}+I_{2 o}^{\prime}=\frac{-j}{\sqrt{2} Z_{o}} \\
& V_{2}=V_{1 e}^{\prime}+V_{1 o}^{\prime}=1, I_{2}=I_{1 e}^{\prime}+I_{10}^{\prime}=\frac{1}{Z_{o}} \\
& V_{3}=V_{1 e}^{\prime}-V_{10}^{\prime}=0, I_{3}=I_{1 e}-I_{1 o}^{\prime}=0
\end{aligned}
$$

가 된다. 이 때

$$
\begin{aligned}
& a_{2}=\frac{1}{2 \sqrt{Z_{o}}}\left(V_{2}+Z_{o} I_{2}\right)=\frac{1}{\sqrt{Z_{o}}} \\
& b_{1}=\frac{1}{2 \sqrt{Z_{0}}}\left(V_{1}+Z_{o} I_{1}\right)=\frac{-j \sqrt{2}}{2 \sqrt{Z_{0}}} \\
& b_{2}=\frac{1}{2 \sqrt{Z_{o}}}\left(V_{3}+Z_{o} I_{3}\right)=0
\end{aligned}
$$

가 되어 각 포트의 입사파와 반사파를 정리하면 다 음과 같다.

$$
S_{22}=0, S_{32}=0, S_{12}=\frac{-j}{\sqrt{2}}
$$

이렇게 구한 결과를 정리하여 분배기의 최종적인 $S$-파라미터를 구하면 다음과 같다.

$$
(S)=\left(\begin{array}{ccc}
0 & \frac{-j}{\sqrt{2}} & \frac{-j}{\sqrt{2}} \\
\frac{-j}{\sqrt{2}} & 0 & 0 \\
\frac{-j}{\sqrt{2}} & 0 & 0
\end{array}\right)
$$

위의 결과는 포트 2 번과 포트 3 번으로 동일한 전 력이 동일한 위상으로 분배됨과 포트 2 와 포트 3 사 이의 고립 특성을 보여준다.

\section{2-2 CRLH 전송 선로 이론}

그림 3(a)는 집중 정수 소자를 이용해서 $\mathrm{RH}$ 전송 선로와 그림 $3(\mathrm{~b})$ 는 $\mathrm{LH}$ 전송 선로의 등가회로를 나 타낸 것이다. 여기서 순수한 LH 전송 선로는 존재하 지 않는데, 그 이유는 직렬 인덕터 $L_{R}$ 은 $\mathrm{LH}$ 전송 선 로의 캐패시터를 구현하는데, 전류가 흐르는 것에 의해서 만들어진 마그네틱 플럭스에 의한 기생 성분 에 의한 것이고, 병렬 캐패시터 $C_{R}$ 은 $\mathrm{LH}$ 전송 선 로의 인덕터 구현시 마이크로스트립과 접지 판 사이 에 존재하는 병렬 판 전압에 의한 기생 성분으로 그 립 3(c)와 같은 CRLH 전송 선로가 현실적으로 이용 된다 ${ }^{[7]}$.

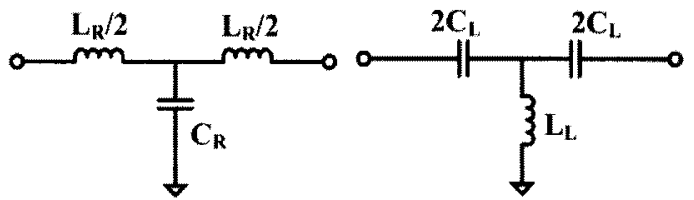

(a) Right-hand 전송 선로 (b) Left-hand 전송 선로

(a) Right-hand transmission (b) Left-hand transmission line line

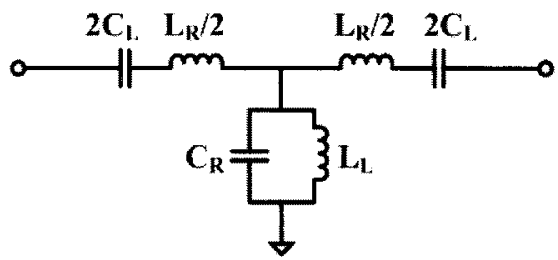

(c) $\mathrm{CRLH}$ 전송 선로

(c) CRLH transmission line

그림 3. T-형태의 단위 셀

Fig. 3. T-type unit cell.

결국 하나의 $\mathrm{CRLH}$ 전송 선로의 위상 천이는 식 (8)과 같이 RH와 LH 전송 선로 위상 천이의 합으로 나타낸다.

$$
\phi_{c}=\phi_{R}+\phi_{L}
$$

이상적인 CRLH 전송 선로의 분산 특성은 그립 4 에 나타내었다.

여기서 CRLH 전송 선로의 분산 특성을 보면, 낮 은 주파수에서는 $\mathrm{LH}$ 전송 선로의 톡성을 나타내고, 변이 주파수를 지나서는 RH 전송 선로의 분산 특성

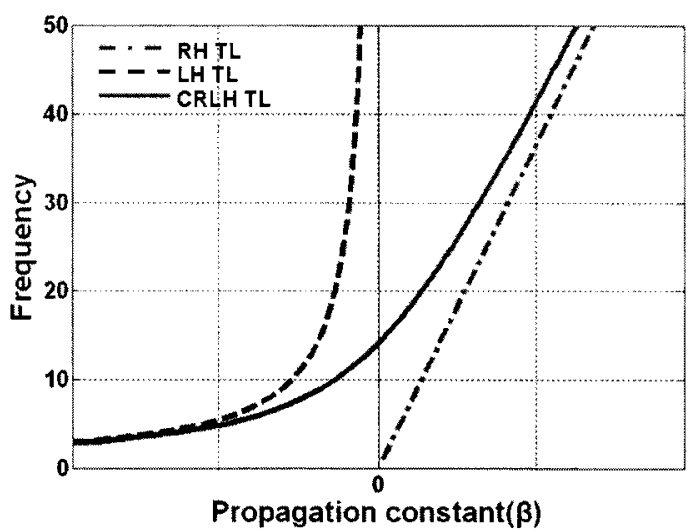

그림 4. RH, $\mathrm{LH}, \mathrm{CRLH}$ 전송 선로의 분산 특성

Fig. 4. Dispersion characteristic of an ideal RH, LH, and CRLH TL. 


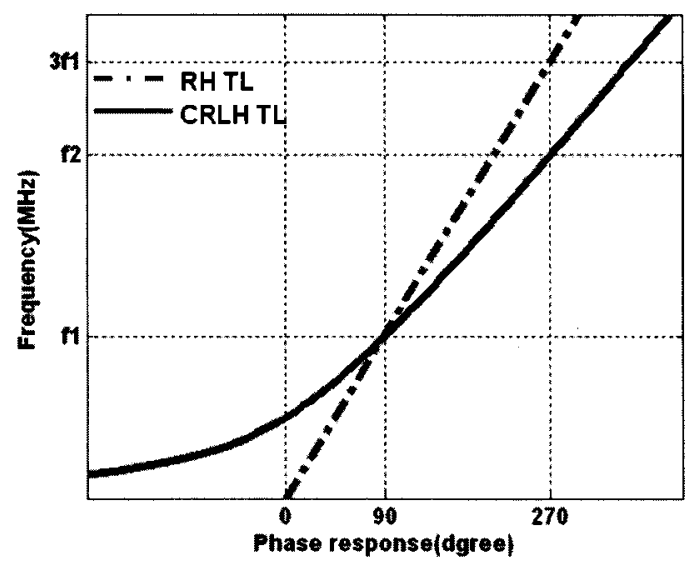

그림 5. 전기적 길이가 $90^{\circ}$ 인 $\mathrm{RH}$ 와 $\mathrm{CRLH}$ 전송 선 로의 위상 특성

Fig. 5. Phase response characteristic of the $\mathrm{RH}$ and CRLH TL in case of $90^{\circ}$ electric length.

을 따라가는 것을 알 수 있다. 이는 저주파에서는 $\mathrm{RH}$ 특성을 나타내는 $L_{R}$ 과 $C_{R}$ 의 존재가 무시되고, 또 한 높은 주파수에서는 $\mathrm{LH}$ 특성을 나타내는 $L_{L}$ 과 $C_{L}$ 의 존재가 무시되기 때문이다.

그림 5 를 보게 되면 이상적으로 설계되어지는 $\lambda$ $14 \mathrm{RH}$ 전송 선로의 위상 특성은 직선적으로 변하는 특성으로, 주파수가 $f_{1}$ 일 때 위상이 $-90^{\circ}$ 이면 $3 f_{1}$ 일때는 위상이 $-270^{\circ}$ 이다.

이와는 달리 $\mathrm{CRLH}$ 전송 선로에서의 위상은 주파 수 $f_{1}$ 에서 $-90^{\circ}$ 이면, 임의의 주파수 $f_{2}$ 에서 그 값이 $-270^{\circ}$ 위상이 되도록 만들 수 있다.

이와 같은 특성을 이용하여 전송 선로를 이중 대 역으로 설계하기 위해서 주파수 $f_{1}, f_{2}$ 를 결정하고, 이 들의 위상 특성을 식 (9)와 같이 $(\pi / 2,-\pi / 2)$ 를 결정 한다.

$$
\phi_{C}\left(f_{1}\right)=\frac{\pi}{2}, \phi_{C}\left(f_{2}\right)=-\frac{\pi}{2}
$$

또한

$$
f_{2}=\alpha f_{1}
$$

논문에서는 $\lambda / 4$ 의 전기적 길이를 갖는 임피던스 의 값이 $50 \Omega$ 과 $70.7 \Omega$ 을 사용하는 두 가지의 전송 선로와 전기적 길이가 $\lambda / 2$ 인 $50 \Omega$ 의 전송 선로, 이 렇게 3 가지의 CRLH 전송 선로를 설계하였다. CRLH 는 두 개의 분포 정수 소자로 RH 전송 선로를 나타

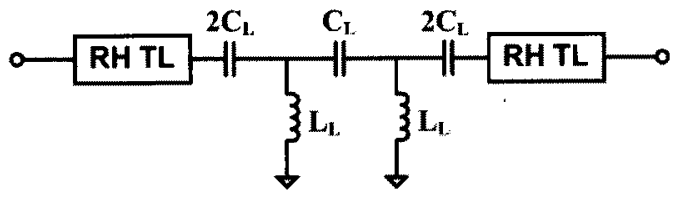

그림 6. 설계된 2단 CRLH 전송 선로

Fig. 6. Design of 2-unit cell CRLH transmission line.

내었고, LH 전송 선로는 집중 소자를 이용하여서 하 나의 전송 선로를 구성하였다.

그림 6의 구조로 이중 대역에서 동작하는 전송 선 로를 설계하였다. 각 소자의 값은 사용하고자 하는 주파수에 맞는 소자 값을 구할 수 있다.

$\phi_{1}=-\beta_{1} l$ 와 $\phi_{2}=-\beta_{2} l$ 이며, 여기서 $l$ 은 전송 선로의 물리적 길이를 의미한다.

$$
\beta\left(\omega_{1}\right)=\beta_{1}, \quad \beta\left(\omega_{2}\right)=\beta_{2}
$$

식 (11)에서 정의한 것과 같이 사용하고자 하는 두 개의 주파수에 해당되는 전달 상수를 정한다. 그 리고 이렇게 정해진 값들로 식 (12)와 식 (13)을 이용 하여 소자 값들을 구할 수 있다.

$$
\begin{aligned}
& \beta^{C R L H}=\omega \sqrt{L_{R} C_{R}}-\frac{1}{\omega \sqrt{L_{L} C_{L}}} \\
& Z_{C}^{C R L H}=\sqrt{\frac{L_{R}}{C_{R}}}=\sqrt{\frac{L_{L}}{C_{L}}}
\end{aligned}
$$

식 (12)와 식 (13)을 식 (11)에 대입하고, $L$ 과 $C$ 의 방정식으로 정리하면 식 (14)에서 식 (17)과 같이 표 현할 수 있다.

$$
\begin{aligned}
L_{R} & =\frac{Z_{t}\left[\phi_{1}\left(w_{1} / w_{2}\right)-\phi_{2}\right]}{N w_{2}\left[1-\left(w_{1} / w_{2}\right)^{2}\right]} \\
C_{R} & =\frac{\phi_{1}\left(w_{1} / w_{2}\right)-\phi_{2}}{N w_{2} Z_{t}\left[1-\left(w_{1} / w_{2}\right)^{2}\right]} \\
L_{R} & =\frac{Z_{t}\left[\phi_{1}\left(w_{1} / w_{2}\right)-\phi_{2}\right]}{N w_{2}\left[1-\left(w_{1} / w_{2}\right)^{2}\right]} \\
C_{L} & =\frac{N\left[1-\left(w_{1} / w_{2}\right)^{2}\right]}{w_{1} Z_{t}\left[\phi_{1}-\left(w_{1} / w_{2}\right) \phi_{2}\right]}
\end{aligned}
$$

여기서 $Z_{t}$ 는 톡성 임피던스, $\phi 1, \phi 2$ 는 전체 위상 변 화, $N$ 은 단위 셀의 수를 나타낸다.

위의 식들로부터 구해진 소자의 값들을 사용하여 전송 선로를 설계하고 $L_{R}, C_{R}$ 값들은 식 (18)의 식으 
표 1. 계산뎐 캐패시터와 인덕터 값, 그리고 RH 전 송 선로의 길이

Table 1. Design of capacitor, inductor values and RH TL length value.

\begin{tabular}{|l|c|c|c|}
\hline & $\begin{array}{c}50 \Omega \\
@ \lambda / 4\end{array}$ & $\begin{array}{c}70.7 \Omega \\
@ \lambda / 4\end{array}$ & $\begin{array}{l}50 \Omega \\
@ \lambda / 2\end{array}$ \\
\hline Capacitance & $2.2 \mathrm{pF}$ & $1.5 \mathrm{pF}$ & $1 \mathrm{pF}$ \\
\hline Inductance & $5.4 \mathrm{nH}$ & $7.7 \mathrm{nH}$ & $2.7 \mathrm{nH}$ \\
\hline $\begin{array}{l}\text { Electric length of } \\
\text { RH TL }\end{array}$ & $100.2^{\circ}$ & $100.2^{\circ}$ & $200.5^{\circ}$ \\
\hline
\end{tabular}

로 RH 전송 선로로 구현하였다.

$$
Z_{C R}=\sqrt{\frac{L_{R}}{C_{R}}}, \phi_{1}^{R H}=-N w_{1} \sqrt{L_{R} C_{R}}
$$

또, $\mathrm{LH}$ 전송 선로는 소자 $C_{L}$ 과 $L_{L}$ 을 이용하여 구 현하였고, 여기에 사용된 인덕터는 고 전력에서 사 용하기 위하여 단락 스터브 회로로 구현하였다. 그 림 6에 나타낸 것처럼 2단으로 구현한 것은 현실적 으로 제작 가능한 인덕터 때문이다. 그래서 위의 식 들을 이용하여 구해진 값들은 포 1 과 같다.

\section{III. 이중 대역 전력 분배기 제작}

앞에서 설명한 고 전력 분배기와 CRLH 전송 선 로를 이용한 이중 대역 특성을 확인하기 위해서 $\mathrm{CR}$ $\mathrm{LH}$ 구조로 설계되어진 이중 대역에서 동작하는 전 송 선로들의 소자들은 고 전력용 소자들로 사용하였 고, 인덕터 대신에 단락 스터브를 병렬로 배치하여 고 전력에서 사용이 가능하도록 설계하였다.

그림 7은 각각의 전송 선로들이 이중 대역 특성의 2-단위 셀 CRLH 구조의 전송 선로로 대체하여 제작 된 고 전력 분배기 사진이다. 이 실혐에서 사용한 기 판은 로저스사의 유전율 3.55 , 두께 $0.813 \mathrm{~mm}$ 를 사 용하였다. 또, 설계된 중심 주파수는 $f_{1}$ 은 $0.88 \mathrm{GHz}$, $f_{2}$ 는 $1.67 \mathrm{GHz}$ 으로 선택하였으며, 이 주파수에서 출 력 특성 값을 확인하였다.

그립 8와 그림 9에서는 전력 분배기의 반사 계수 가 $-15 \mathrm{~dB}$ 이상과 삽입 손실은 $0.8 \mathrm{~dB}$ 이하를 나타 내고 있으며, 설계한 이중 대역 $0.88 \mathrm{GHz}$ 와 1.67 $\mathrm{GHz}$ 에서의 $\mathrm{ADS}$ 시뮬례이션과 실험 결과가 거의 동 일함을 보여준다. 또, 그림 9에서 시뮬레이선 값이

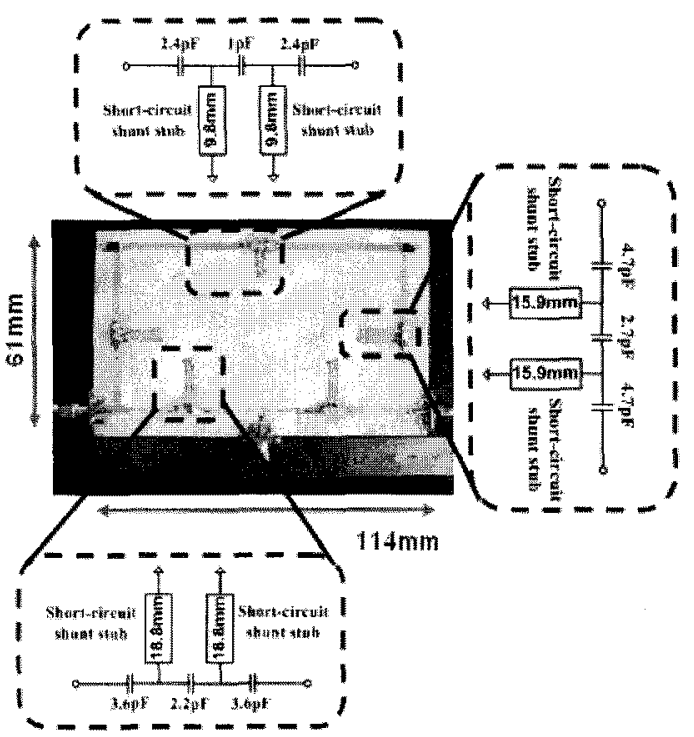

그림 7. 제작된 이중 대역 전력 분배기 사진

Fig. 7. Photograph of dual-band high power divider.

$1.1 \mathrm{GHz}$ 부근에서 $S_{21}$ 이 $3 \mathrm{~dB}$ 특성이 나오지만 $S_{11}$ 값 이 $5 \mathrm{~dB}$ 밖에 되지 않아 사용할 수 없는 구간으로 판 단된다. 포트 2 와 3 사이의 격리도는 실계한 두 주파 수에서 8 10 dB가 되는 것을 확인하였다.

또, 그림 10 은 분배기의 각 포트 간의 위상을 나 타낸 것으로 그 차이가 $3 \sim 6^{\circ}$ 오차를 가지는 것을 보

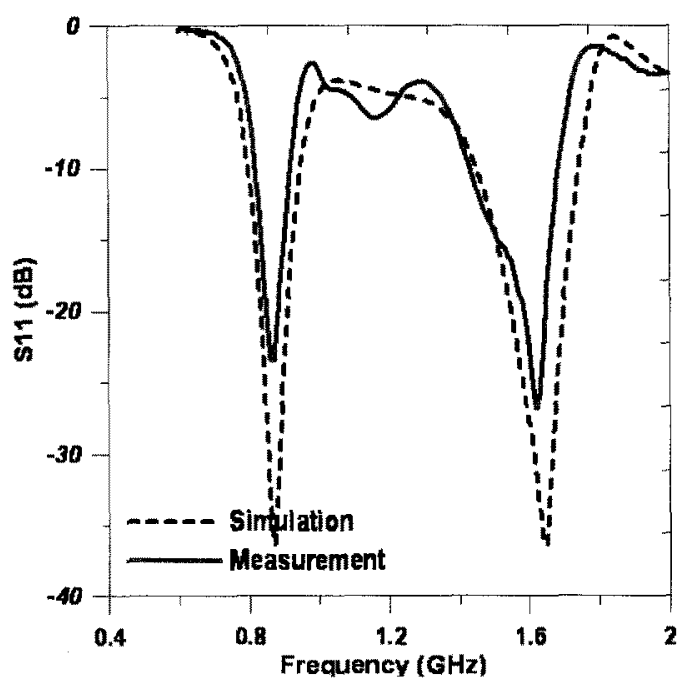

그림 8. 반사 계수 시뮬레이션 결과와 실제 측정값 비교

Fig. 8. Comparison return loss of simulation and measured result. 


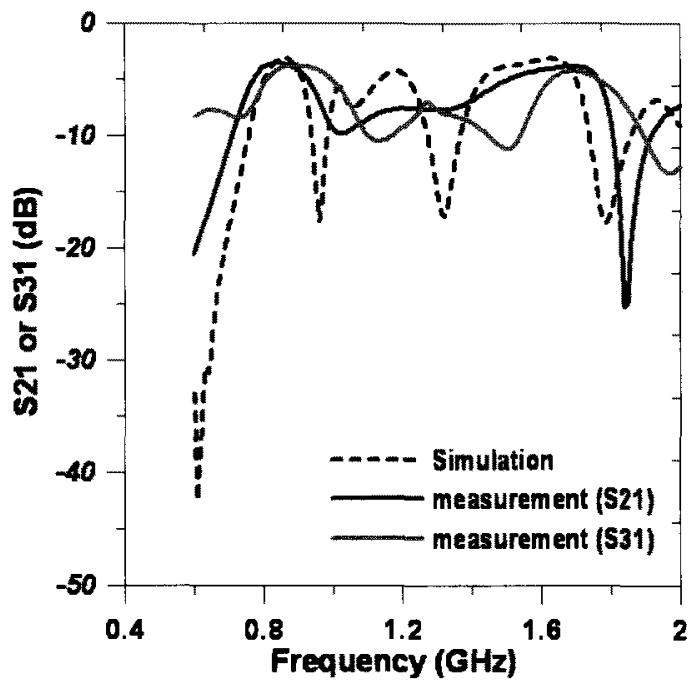

그림 9. 투과계수 시뮬레이션 결과와 실제 측정값 비료

Fig. 9. Comparison insertion loss of simulation and measured result.

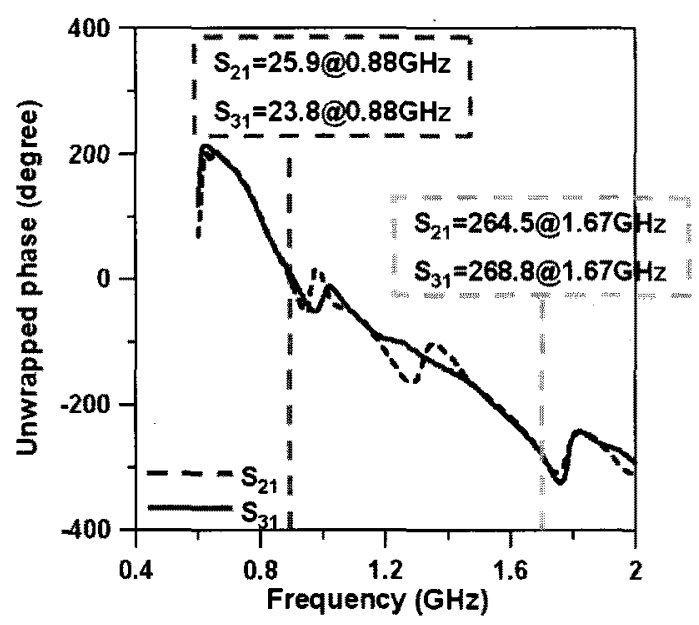

그림 10. 출력 포트의 위상

Fig. 10. Phase value of output port.

여주고 있고, 시뮬레이선과 실험 결과는 거의 동일 한 것을 확인하였다.

\section{IV. 결 론}

본 논문에서는 CRLH 전송 선로를 이용하여 이중 대역과 고 전력에서 사용할 수 있는 전력 분배기를 설계 및 제작하였다.
제작된 분배기는 $0.88 \mathrm{GHz}, 1.67 \mathrm{GHz}$ 의 두 주파수 에서 각각 $3.83 \mathrm{~dB}, 3.64 \mathrm{~dB}$ 의 삽입 손실과 반사 손실 이 $-21 \mathrm{~dB},-15.6 \mathrm{~dB}$ 값을 언어 이중 대역에서 동 작하는 것을 확인하였다. 또한, 두 출력 포트의 위상 값은 거의 동일한 값으로 측정되었다.

이와 같이 CRLH 전송 선로로 설계되어진 이중 대역 고 전력 분베기는 단말기에 이용할 수 있으며, 다중 대역 전력 분배기/결합기가 무선 시스템의 송. 수신 단에 적용되면 시스템의 소형화와 손실을 줄일 수 있어 시스템 성능을 향상시킬 수 있을 것으로 기 대된다.

\section{참 고 문 헌}

[1] H. Okabe, C. Caloz, and T. Itoh, "A compact enhanced-bandwidth hybrid ring using an artifical lumped-element left-handed transmission line section", IEEE Transactions on Microwave Theory and Techniques, vol. 52, no. 3, pp. 798-804, Mar. 2004.

[2] 임종식, 박웅희, 정용채, 안달, 오성민, 구재진 김광수, "다단 윌킨슨 구조의 초광대역 $\mathrm{CPW}$ 발 룬", 한국전자퐈학회논문지, $17(9)$, pp. 811-820, 2006년 9월.

[3] L. I. Parad, R. L. Moynihan, "Split-tee power divider", IEEE Transactions on Microwave Theory and Techniques, vol. 13, Issue 1, pp. 91-95, Jan. 1965.

[4] R. C. Edwards, "Wideband transmission line signal combiner/divider", United States Patent 4,774,481, Sep. 1988.

[5] V. G. Veselago, "The electrodynamics of substances with simultaneously negative values of $\varepsilon$ and $\mu^{\prime \prime}$, Soviet Physics Uspekhi, vol. 10, no. 4, pp. 509524, Jan. -Feb. 1968.

[6] C. Caloz, T. Itoh, Electromagnetic Metamaterials: Transmission Line Theory and Microwave Applications, Wiley \& Sons Inc., 2006.

[7] E. Saenz, A. Cantora, I. Ederra, R. Gonzalo, and P. de Maagt, "A metamaterial T-junction power divider", IEEE Microwave and Wireless Components Letters, vol. 17, no. 3, Mar. 2007. 
[8] X. Q. Lin, R. P. Liu, X. M. Yang, J. X. Chen, X. $X$. Yin, Q. Cheng, and T. J. Cui, "Arbitrarily dualband components using simplified structure of conventional CRLH-TLs", IEEE Transactions on Microwave Theory and Techniques, vol. 54, no. 7, pp. 2902-2909, Jul. 2006.

[9] Ulrich H. Gygel, "A new n-way divider/combiner

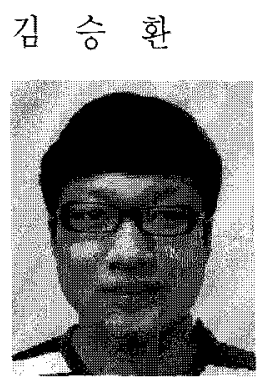

2008년 2월: 금오공과대학교 전자 공학북 전자공학과 (공학사)

2008년 3월 현재: 금오공과대햑교 전표동신공학과 석사과정

[주 관심분애] RF 혀로 솔계, Metamaterial, 수동소차 회로 설계, 고 효율 전력 증폭기 설계

\section{손 강 호}

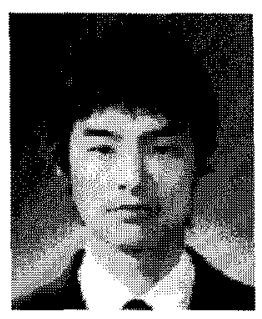

2008젼 2월: 금오공과대학교 전자 공학부 전사공학과 (공학사) 2008년 3월 현재: 금오공과대학교 전피통신공항과 석사과정

[주 관심분야] 광대역 증폭기 및 선 형화기, 수동 필터 설계

suitable for high-power applications", IEEE MTT Int'l Symp., vol. 75, Issue 1, pp. 116-118, May 1975.

[10] David M. Pozar, Microwave Engineering, John Wiley \& Sons, Inc., pp. 368-373, 2005.

[11] E. Wilkinson, "An N-way hybrid power divider", IRE Transaction on Microwave Theory and Techniques, vol. MTT-8, pp. 116-118, Jan. 1960.

\section{김 영}

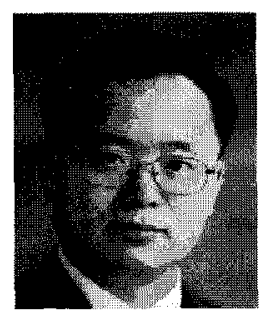

1988 년 2월: 서강대학교 전자공학 과 (공학석사)

2002년 8월: 서강대학교 전자공학 과 (공학박사)

1988년 1월 -1993년 5월: 이즈텔시 스템즈(주) 연구소 선임연구원 1993년 6월 - 1998년 2월: 삼성전자 (주) 정보통신사업본부 선임연구원

1998년 3월 - - 2003년 2월: 두원공과대항 정보동신과 조교 수

2003년 3월 현재: 금오공과대학교 전자공학부 조교수 [주 관심분야] RF 및 Microwave 회로해석 및 설계, 전력 증폭기 및 선형화기 설계

이 영 순

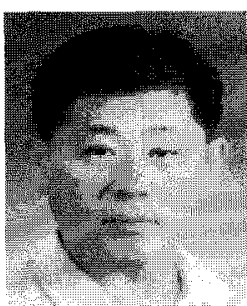

1979년 2월: 경북대학교 전자공학 과 (공학사)

1981년 2월: 한국과학기술원 전자 공학과 (공학석사)

1996년 2월: 경북대학교 전자공학 과 (공학박사)

1981년 현재: 금오공과대학교. 전 자공학부 교수

[주 관심분야] 전자기 이론, 안테나의 산란 문제, 도마관 불연속, 개구 결합

윤 영 철

2005 년 2월: 금오공과대학교 전자 공학부 전자공학과 (공학사)

2005년 3월 2007년 2월: 금오공과 대학교 전파통신공학과 (공학석 사)

2007년 3월 - 현재: 금오공과대학교 전파통신공학과 바사과정

[주 관심분애] RF 회로 설 계, 고효율 전럭 증폭기 및 선형 화기 설계

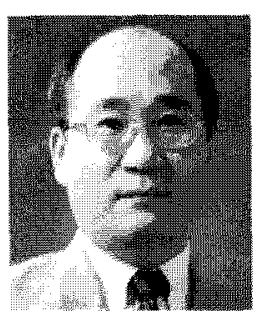

1978년 2월: 서강대학교 전자공학 과 (공학사)

1982년 2월; 서강대학교 전자공학 과 (공학석사)

1989년 2월: 서강대학교 전자공학 과 (공학박사) 자정보통신공학부 교수

[주 관심분여] RF 및 Microwave 회로설계
1987년 9월 현재: 관동대학교 전 